\title{
Trace element concentrations of size-fractionated particulate matter in the atmosphere of Istanbul, Turkey
}

\author{
Ü. Alver Şahin, B. Onat \& G. Polat \\ Engineering Faculty, Environmental Engineering Department, \\ Istanbul University, Turkey
}

\begin{abstract}
In this study, the physical characteristics and metal contents of particulate matter (PM) have been determined. In this scope, PM sampling has been done at 5 stations (Avcılar, Beşiktaş, Kilyos, Rasathane, Göztepe) for 2 years. PM filter samples were collected for 8 different $\operatorname{size}(<0.43 \mu \mathrm{m}, 1-0.43 \mu \mathrm{m}, 1-1.7 \mu \mathrm{m}, 1.7-$ 2.6 $\mu \mathrm{m}, 2.6-3.5 \mu \mathrm{m}, 3.5-5 \mu \mathrm{m}, 5.2-6.5 \mu \mathrm{m}, 6.5-8 \mu \mathrm{m}$ and $>8 \mu \mathrm{m})$ using the cascade impactor. PM filters were decomposed and analyzed for 8 metals $(\mathrm{Cr}$, $\mathrm{Mn}, \mathrm{Fe}, \mathrm{Cu}, \mathrm{Pb}, \mathrm{Ni}, \mathrm{Cd}$ and $\mathrm{V}$ ). According to the results, trace element concentrations at all the stations were at least 2 times higher than at the Kilyos station which was selected as the urban background station. $\mathrm{Pb}, \mathrm{Cd}$ and $\mathrm{V}$ elements are mainly present in fine fraction of $\mathrm{PM}$, while $\mathrm{Cu}, \mathrm{Mn}$ and $\mathrm{Fe}$ mass is found in coarse fraction of PM. Mass Median Aerodynamic Diameter (MMAD) values for crustal element ( $\mathrm{Fe}, \mathrm{Cr}, \mathrm{Cu}$ and $\mathrm{Mn}$ ) were found to be in the coarse size fraction and anthropogenic element $(\mathrm{Pb}, \mathrm{Cd}$ and $\mathrm{V})$ were found to be in the fine particles. The major PM source was observed industrial facilities at the Avcılar; traffic and domestic heating at the Beşiktaş, Göztepe and Rasathane.

Keywords: air pollution, particulate matter, trace metals, size distribution, Istanbul.
\end{abstract}

\section{Introduction}

Atmospheric particles have a direct impact on health through respiration, and this effect is related to the physical and chemical properties of the particles. The efficiency of inhalation and respiratory deposition of particulate matter (PM) is dependent on the size of the particles [1]. Therefore, knowledge of particle size 
is vital in understanding the effects of PM on human health. Particles that are less than $10 \mu \mathrm{m}$ in diameter have the potential to reach the lower respiratory tract from the nose down to the alveoli. Particles larger than $5 \mu \mathrm{m}$ in diameter are usually filtered out by the nose. Fine particles with diameters of less than $2 \mu \mathrm{m}$ reach deep into the alveolar regions of the human lung, where the absorption efficiency for trace elements is in the range of $60-80 \%$. The chemical components in anthropogenic PM range from 0.001 to $2 \mu \mathrm{m}$ in diameter [1,2].

Many researchers in Europe and Asia have conducted experiments to study the size distribution of PM in the last decade [3-15]. However, there have only been a few studies conducted in Turkey investigating $\mathrm{PM}_{10}$ and even fewer studies investigating $\mathrm{PM}_{2.5}$ [16-19]. Furthermore, the size distribution of PM has been studied in Turkey limited number in the last year [20, 21]. In this study, the size distributions of particles at different locations in Istanbul across four seasons from 2008 to 2010 were investigated.

\section{Materials and methods}

Istanbul, located on the extremities of Asia and Europe, is the most populated city in Turkey, with a population of approximately 13 million. The city has 11,143 industrial establishments and 2,500,000 registered motor vehicles. In this study, inhalable particulate matter (PM) was sampled at five stations (Figure 1). The Avcilar urban station $\left(40^{\circ} 59^{\prime} 21.45^{\prime \prime} \mathrm{N}, 28^{\circ} 43^{\prime} 19.64 " \mathrm{E}\right)$ has high levels of vehicle, industrial and residential emissions. The Beşiktaş urban sampling station $\left(41^{\circ} 3^{\prime} 6.59^{\prime \prime} \mathrm{N}, 2^{\circ} 0^{\prime} 35.82^{\prime \prime} \mathrm{E}\right)$ is located in a residential and commercial area, where the pollution sources are residents' activities and vehicular emissions. The Rasathane urban sampling station $\left(41^{\circ} 3^{\prime} 48.54^{\prime \prime} \mathrm{N}, 2^{\circ} 3^{\prime} 52.26^{\prime \prime} \mathrm{E}\right)$ is located in a residential area. The Göztepe urban sampling station $\left(40^{\circ} 59^{\prime} 47.36 " \mathrm{~N}\right.$,

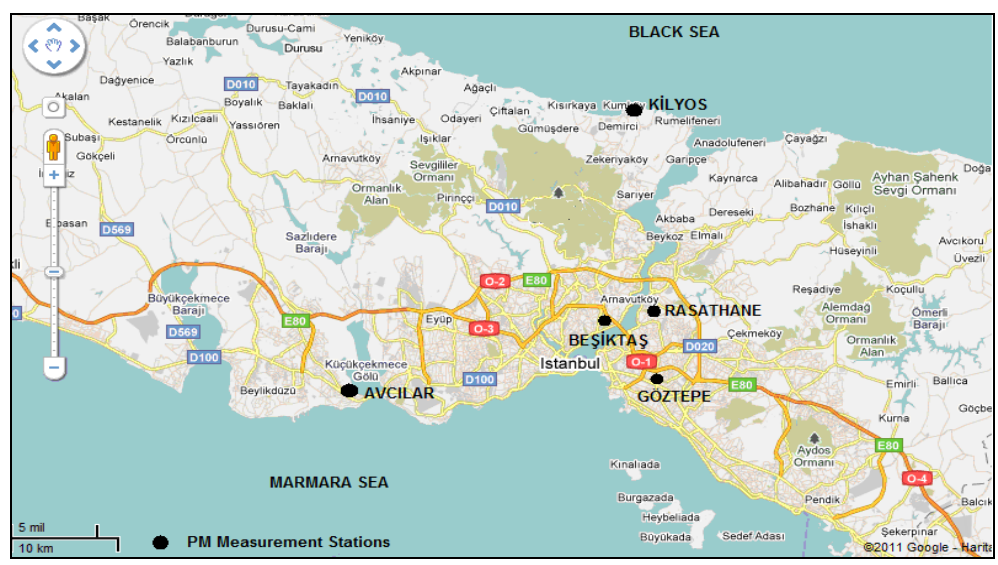

Figure 1: The particulate matter sampling locations of the study area in Istanbul, Turkey (www.maps.google.com). 
$29^{\circ} 3^{\prime} 58.58^{\prime \prime E}$ ), which is near the D100 highway, has vehicle and residential emissions. The fifth sampling station is the Kilyos rural sampling station $\left(41^{\circ} 14^{\prime} 36.60^{\prime \prime} \mathrm{N}, 2^{\circ} 0^{\prime} 48.60^{\prime \prime} \mathrm{E}\right)$, which is occupied by very few residents. The sampling locations and size distribution analyses of PM were described in detail in our previous study [21].

PM were collected using a non-viable Andersen impactor with an airflow rate of $90 \mathrm{lpm}$. Quartz fiber filters (QF) with 81-mm diameters were used for the gravimetric and metal analysis. The Anderson impactor consists of eight stages (labeled 0-7) and an additional stage F (backup filter), with size selection parameter divisions in terms of the particle aerodynamic diameter (dp) as follows: $>8,8-6.5,6.5-5.2,5.2-3.5,3.5-2.6,2.6-1.7,1.7-1,1-0.43$ and $<0.43 \mu \mathrm{m}$. Sampling was carried out from July 2008 to August 2010. A total of 16 PM samples were collected at each station. The duration of sampling in a single station was approximately $7 \pm 2$ days. The filters within the impactor were transferred to clean Petri dishes with tweezers in a closed environment and were then brought into the laboratory. Following the removal of the filters, the impactor was cleaned. Clean filters were then installed before the system was taken to the next station. The sampling procedure and gravimetric analysis of the PM were described in detail in our previous studies [20, 21]. After tha gravimetric analysis, the aerosol samples were stored in the refrigerator at approximately $4^{\circ} \mathrm{C}$ prior to extraction.

The dust filters were decomposed in three different steps using microwave equipment (Cem Mars Xpress, microwave digestion system, USA). At the first step, $6 \mathrm{ml}$ of $\mathrm{HNO}_{3}$ and $2 \mathrm{ml}$ of $\mathrm{H}_{2} \mathrm{O}_{2}$ were added to the dust filters and were allowed to decompose for 40 minutes at $180^{\circ} \mathrm{C}$. At the second step, $2 \mathrm{ml} \mathrm{HCl}$ was added to the extract and the decomposition time was 35 minutes at $175^{\circ} \mathrm{C}$. In the final step, $2 \mathrm{ml} \mathrm{HF}$ was added to the extract and the decomposition time was 30 minutes at $160^{\circ} \mathrm{C}$. The most effective results were observed with this threestep decomposition process. At the end of the decomposition, the filters were completely dissolved. A rotating turntable (3-6 rpm) capable of holding 10 closed digestion vessels (PTFE) ensured even sample heating. The samples were digested and cooled as per the program setting, after which the sample solution was directly diluted to $30 \mathrm{ml}$ at $25^{\circ} \mathrm{C}$ with deionized distilled water and stored in the refrigerator at approximately $-4^{\circ} \mathrm{C}$ prior to analysis.

To measure the metal concentration in the solution, graphite atomic absorption spectrophotometry (Perkin Elmer GF-AAS 600) was employed. This unit was operated with the Zeeman background correction on, and the peak area was integrated for all signals. To evaluate the accuracy of the analytical methods and to establish the optimal digestion conditions, the NIST Urban Particulate Matter (SRM 1648) was used as references. One mg of SRM 1648 was digested using the method described earlier to examine the capabilities of the analytical methods and to perform the recovery procedure. All elements had recoveries between $\% 95$ and $\% 103$. We selected one quartz filter as blank every PM sampling. Limits of detection (LODs), calculated as three times the standard deviation of blank samples, and were satisfactory for environmental monitoring. The mass concentrations of metals are well above these blank values. 


\section{Results and discussion}

The concentrations of inhalable particulate matter and metal contents of eight size ranges at different locations in Istanbul were determined. The total metal concentration in total particulate matter (TPM), fine to coarse ratio $(<2.6 \mu \mathrm{m}$ $>2.6 \mu \mathrm{m}, \mathrm{F} / \mathrm{C}$ ), mass median aerodynamic diameters (MMADs) of metals and differs from background station (Kilyos) in all stations (Avcılar, Beşiktaş, Rasathane, Göztepe) are displayed in Table 1.

The highest mean $\mathrm{Pb}, \mathrm{Ni}, \mathrm{Cd}, \mathrm{Cr}, \mathrm{V}, \mathrm{Mn}, \mathrm{Cu}, \mathrm{Fe}$ concentrations in TPM was measured at the Avcılar, Beşiktaş and Göztepe stations (Table 1). The lowest mean metal values were measured at the Kilyos station. The total mean $\mathrm{Pb}, \mathrm{Cd}$ and Ni concentrations at the Avcilar station were 3.5, 2.3 and 1.7 times higher, $\mathrm{Cr}$ and $\mathrm{V}$ at the Beşiktaş station were 2.1 and 2.6 times higher and $\mathrm{Cu}, \mathrm{Mn}$ and Fe 8.7, 1.9 and 2.7 times higher than at the Kilyos station, which was selected as the city background. The $\mathrm{Pb}$ and $\mathrm{Cd}$ metals are major emissions of the cement factory [16]. The cement factory located in the north of the Avcilar sampling station can cause an increase of the $\mathrm{Pb}$ and $\mathrm{Cd}$ concentrations in Avcrlar. Some studies showed that $\mathrm{Pb}$ and $\mathrm{Cd}$ elements were the indicator elements of the traffic emissions [22-24]. The highest concentrations were observed at Beşiktaş, Göztepe and Avcilar stations. The major PM source of these stations was traffic. Additionally, $\mathrm{V}$ and $\mathrm{Fe}$, can be found in the composition of road dust, were also higher at the same stations.

The annual average limit values of $\mathrm{Pb}, \mathrm{Cd}$ and $\mathrm{Ni}$ metal in $\mathrm{PM}_{10}$ are given as $500 \mathrm{ng} / \mathrm{m}^{3}, 5 \mathrm{ng} / \mathrm{m}^{3}$ and $20 \mathrm{ng} / \mathrm{m}^{3}$ by 99/30/EC EU-Directive (99/30/EC EUDirective), respectively. In this study, $\mathrm{Cd}, \mathrm{Pb}$ and $\mathrm{Ni}$ concentrations were found below the limit values. In a recent study in Istanbul, Theodosi et al. [25] found that the $\mathrm{Ni}$ and $\mathrm{Cd}$ was $7 \mathrm{ng} / \mathrm{m}^{3}$ and $1 \mathrm{ng} / \mathrm{m}^{3}$, respectively, and their results were similar to this study.

The highest $\mathrm{F} / \mathrm{C}$ ratios are observed for $\mathrm{Pb}$ at all stations, especially higher at the Avcilar and Rasathane stations. $\mathrm{F} / \mathrm{C}$ ratios for $\mathrm{Cd}$ are changing between 1.1 and 2.0 and for $\mathrm{V}$ equal to $1 . \mathrm{Pb}, \mathrm{Cd}$ and $\mathrm{V}$ elements are mainly present in fine fraction of PM, while $\mathrm{Cu}, \mathrm{Mn}$ and $\mathrm{Fe}$ mass with $\mathrm{F} / \mathrm{C}$ ratios approximately 0.5 is found in coarse fraction of PM. Similar results were reported by Karanasiou et al. [26].

Fig. 2 summarizes the size distributions of trace elements at all stations. The size distribution of $\mathrm{Pb}, \mathrm{Cd}$ and $\mathrm{V}$ have their peaks mainly between $1 \mu \mathrm{m}$ and $0.43 \mu \mathrm{m}$ fraction at Avcılar, Göztepe and Beşiktaş stations, respectively. This fine particles accumulations showed to be anthropogenic sources at these areas. In general, the mass size distributions in crustal trace metals (Fe and $\mathrm{Mn}$ ) and $\mathrm{Cr}$ showed coarse particle accumulation which was characterized by relatively higher peak at the size above $6.5 \mu \mathrm{m}$. The other anthropogenic metal, $\mathrm{Ni}$, showed bimodal patterns with primary peak at the size range of $0.43-1 \mu \mathrm{m}$, and secondary peak at the size range of 2.6-5.2 $\mu \mathrm{m}$ (Fig. 2). $\mathrm{Cu}$ is known that important finger print of brake wear source [27]. So the size distribution of $\mathrm{Cu}$ showed main peak at the size range of 1.7-3.5 $\mu \mathrm{m}$ at the Göztepe and Beşiktaş stations which are near main traffic road (Fig. 1). The results showed that the 
traffic is the first major source of PM and the second major source is domestic heating. In addition, road dust was an important component of atmospheric PM and $\mathrm{Mn}, \mathrm{Cu}$ and $\mathrm{Fe}$ elements were found higher in coarse PM.

Table 1: MMAD values for metal concentration (mean and standard deviation, $\left.\mathrm{ng} / \mathrm{m}^{3}\right)$ in total particulate matter $(\mathrm{TPM})$, fine $(<2.6 \mu \mathrm{m})$ to coarse $(>2.6 \mu \mathrm{m})$ ratios $(\mathrm{F} / \mathrm{C})$, MMADs and differs from background station in all stations (Avcılar, Beşiktaş, Göztepe, Rasathane, Kilyos).

\begin{tabular}{|c|c|c|c|c|c|c|c|c|}
\hline \multirow{3}{*}{$\begin{array}{l}\text { Stations } \\
\text { AVCILAR }\end{array}$} & \multicolumn{8}{|c|}{ Metals } \\
\hline & $\mathrm{Cr}$ & $\mathrm{Ni}$ & $\mathrm{Pb}$ & $\mathrm{Cu}$ & $\mathrm{Cd}$ & $\mathrm{Mn}$ & $\mathrm{V}$ & $\mathrm{Fe}$ \\
\hline & & & & & & & & \\
\hline Mean & 7.0 & 4.8 & 16.7 & 5.9 & 0.9 & 16.4 & 2.6 & 1100.6 \\
\hline SD & 3.1 & 3.9 & 10.6 & 3.6 & 0.5 & 11.2 & 2.1 & 666.7 \\
\hline $\mathrm{F} / \mathrm{C}$ & 0.6 & 0.7 & 3.2 & 0.5 & 1.1 & 0.5 & 0.9 & 0.5 \\
\hline MMADs & 3.3 & 2.9 & 1.3 & 4,1 & 2.3 & 3.9 & 2.2 & 4.2 \\
\hline A/Background & 1.8 & 1.7 & 3.5 & 2.7 & 2.3 & 1.8 & 2.2 & 2.3 \\
\hline BEŞİKTAŞ & & & & & & & & \\
\hline Mean & 7.9 & 4.3 & 7.3 & 15.0 & 0.7 & 13.6 & 3.1 & 1034.9 \\
\hline SD & 3.7 & 1.8 & 4.8 & 7.2 & 0.3 & 6.7 & 1.9 & 364.9 \\
\hline $\mathrm{F} / \mathrm{C}$ & 0.7 & 0.6 & 1.9 & 0.4 & 1.1 & 0.4 & 1.2 & 0.3 \\
\hline MMADs & 3.1 & 3.4 & 1.4 & 4.0 & 2.2 & 4.4 & 1.7 & 4.4 \\
\hline B/Background & 2.1 & 1.5 & 1.5 & 6.8 & 1.8 & 1.5 & 2.6 & 2.1 \\
\hline RASATHANE & & & & & & & & \\
\hline Mean & 4.4 & 3.1 & 5.5 & 5.4 & 0.5 & 7.6 & 1.6 & 564.4 \\
\hline SD & 2.2 & 1.8 & 3.7 & 4.3 & 0.3 & 4.2 & 1.1 & 261.9 \\
\hline $\mathrm{F} / \mathrm{C}$ & 0.7 & 0.7 & 3.0 & 0.6 & 1.6 & 0.7 & 1.6 & 0.5 \\
\hline MMADs & 2.9 & 3.1 & 0.8 & 3.8 & 1.8 & 3.0 & 1.2 & 3.7 \\
\hline R/Background & 1.2 & 1.1 & 1.1 & 2.5 & 1.3 & 0.9 & 1.3 & 1.2 \\
\hline GÖZTEPE & & & & & & & & \\
\hline Mean & 7.5 & 3.8 & 10.8 & 19.1 & 0.6 & 16.7 & 2.7 & 1303.4 \\
\hline SD & 3.2 & 2.5 & 14.8 & 10.6 & 0.6 & 5.5 & 2.0 & 595.2 \\
\hline $\mathrm{F} / \mathrm{C}$ & 0.6 & 0.3 & 2.1 & 0.5 & 2.0 & 0.5 & 0.9 & 0.5 \\
\hline MMADs & 3.3 & 4.2 & 1.7 & 3.6 & 1.0 & 3.7 & 2.5 & 4.0 \\
\hline G/Background & 2.0 & 1.3 & 2.3 & 8.7 & 1.5 & 1.9 & 2.3 & 2.7 \\
\hline KİLYOS & & & & & & & & \\
\hline Mean & 3.8 & 2.9 & 4.8 & 2.2 & 0.4 & 8.9 & 1.2 & 486.2 \\
\hline SD & 2.1 & 1.6 & 3.6 & 0.9 & 0.3 & 4.1 & 0.4 & 263.5 \\
\hline $\mathrm{F} / \mathrm{C}$ & 0.5 & 0.5 & 1.8 & 0.5 & 1.1 & 0.5 & 1.3 & 0.5 \\
\hline MMADs & 3.7 & 3.9 & 2.0 & 4.2 & 2.1 & 4.1 & 1.8 & 4.1 \\
\hline
\end{tabular}



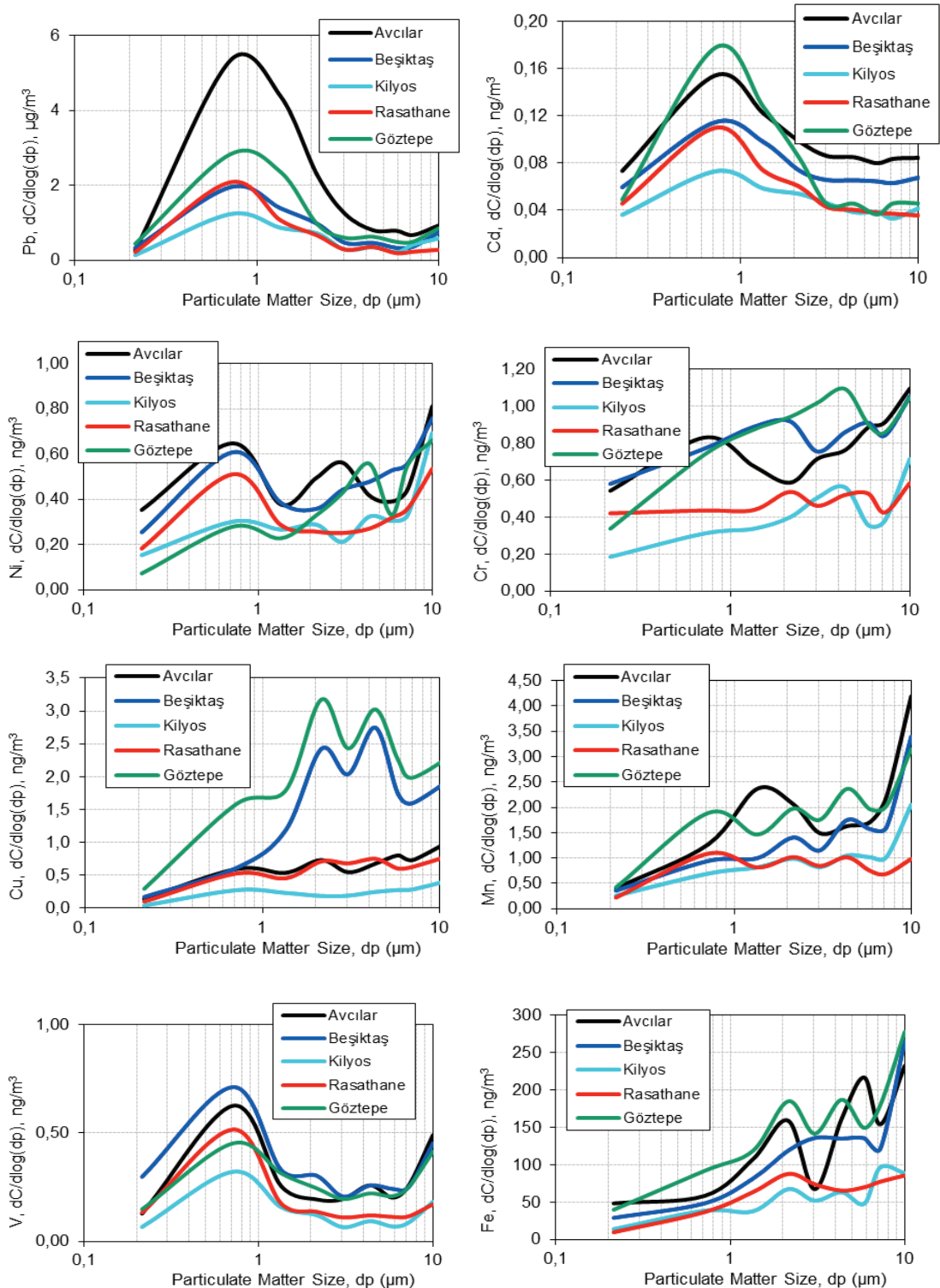

Figure 2: $\quad$ The mass size distribution of the mean metals in the five stations.

As seen in Fig. 2 the mass size distribution of a particular compound-species is approximately lognormal and unimodal. So the mass median aerodynamic diameter (MMADs) and the geometric standard deviation (GSD) are able to define this type of distribution $[1,26,28]$. The cumulative size distribution was 
constructed using the method which described detailed in our previous study [21]. Using the regression lines of the log-normal distribution, mean MMAD were calculated for every element. In the case of particle metal concentrations a least-square fit, $\mathrm{R}^{2}$ values greater than 0.95 indicating that these metals have a unimodel distribution. MMADs results are given in Table 1. MMAD values for $\mathrm{Fe}, \mathrm{Cr}, \mathrm{Cu}$ and $\mathrm{Mn}$ were found to be in the coarse size fraction, indicating crustal contribution, $\mathrm{Pb}, \mathrm{Cd}$ and $\mathrm{V}$ were found to be in the fine particles $(<2.6 \mu \mathrm{m})$, indicating anthropogenic contribution. In addition to this, as can be seen in Table 1, there is a strong negative correlation between MMADs values and $\mathrm{F} / \mathrm{C}$ values, change from 0.55 and 0.99 . These results are similar to Karanasiou et al. [26] study results.

In many studies on air pollution, the heating and the non-heating seasons are differentiate $[17,21,29,30]$. Domestic heating in densely populated residential areas is a significant source of air pollution in İstanbul. For this reason, the data obtained in this study were considered in terms of heating and non-heating periods. In determining these periods, the local air temperatures during the sampling periods were considered. Periods when the air temperature was above $18^{\circ} \mathrm{C}$ were considered non-heating periods and the rest were considered heating periods. The metal concentration ratio of heating and non-heating season in three size fractions is shown Table 2.

Table 2: The metal concentration ratio of heating and non-heating season in three size fractions $(<1 \mu \mathrm{m}, 1-2.6 \mu \mathrm{m},>2.6 \mu \mathrm{m})$.

\begin{tabular}{cccccccccc}
\hline Stations & PM Size $(\mu \mathrm{m})$ & $\mathrm{Cr}$ & $\mathrm{Ni}$ & $\mathrm{Pb}$ & $\mathrm{Cu}$ & $\mathrm{Cd}$ & $\mathrm{Mn}$ & $\mathrm{V}$ & $\mathrm{Fe}$ \\
\hline \multirow{4}{*}{ AVCILAR } & $<1$ & 1.0 & $\mathbf{1 . 4}$ & 1.0 & 0.9 & $\mathbf{1 . 8}$ & 1.1 & 0.6 & $\mathbf{1 . 7}$ \\
& $1-2.6$ & $\mathbf{1 . 3}$ & $\mathbf{2 . 6}$ & $\mathbf{1 . 9}$ & 0.5 & $\mathbf{1 . 5}$ & 0.9 & 0.7 & 0.6 \\
& $>2.6$ & 1.1 & $\mathbf{1 . 7}$ & 0.6 & 0.5 & $\mathbf{1 . 5}$ & 1.0 & 0.5 & 0.7 \\
\hline \multirow{3}{*}{ BEŞiKTAŞ } & $<1$ & 0.9 & 0.8 & $\mathbf{2 . 0}$ & 1.1 & 1.1 & $\mathbf{1 . 8}$ & 1.1 & 0.6 \\
& $1-2.6$ & $\mathbf{1 . 5}$ & 0.9 & $\mathbf{2 . 3}$ & 1.0 & 1.1 & $\mathbf{1 . 4}$ & 1.2 & 0.7 \\
& $>2.6$ & 1.3 & 0.5 & 1.2 & 1.1 & 0.8 & $\mathbf{1 . 4}$ & 1.1 & 0.8 \\
\hline \multirow{3}{*}{ GÖZTEPE } & $<1$ & 1.2 & $\mathbf{2 . 2}$ & $\mathbf{3 . 3}$ & $\mathbf{1 . 9}$ & $\mathbf{2 . 0}$ & $\mathbf{1 . 4}$ & $\mathbf{1 . 8}$ & $\mathbf{1 . 5}$ \\
& $1-2.6$ & 1.1 & $\mathbf{1 . 5}$ & $\mathbf{3 . 1}$ & $\mathbf{1 . 3}$ & $\mathbf{1 . 3}$ & 1.1 & $\mathbf{2 . 4}$ & 1.2 \\
& $>2.6$ & 1.1 & 1.0 & $\mathbf{1 . 3}$ & 1.2 & 0.8 & 1.1 & $\mathbf{1 . 6}$ & 1.0 \\
\hline \multirow{4}{*}{ RASATHANE } & $<1$ & 0.8 & 0.8 & $\mathbf{1 . 7}$ & 1.0 & 1.0 & $\mathbf{1 . 8}$ & 0.8 & 0.9 \\
& $1-2.6$ & 1.0 & 0.7 & 1.2 & 0.8 & 0.8 & $\mathbf{1 . 3}$ & 1.1 & 0.9 \\
& $>2.6$ & 0.9 & 0.9 & 0.9 & 0.4 & 0.6 & 1.0 & $\mathbf{1 . 4}$ & 0.7 \\
\hline \multirow{3}{*}{ KİLYOS } & $<1$ & $\mathbf{2 . 4}$ & 0.8 & $\mathbf{1 . 8}$ & 1.1 & $\mathbf{2 . 7}$ & $\mathbf{1 . 3}$ & 1.0 & 1.0 \\
& $1-2.6$ & $\mathbf{1 . 5}$ & 1.1 & $\mathbf{1 . 8}$ & 1.0 & $\mathbf{2 . 1}$ & 0.7 & 1.1 & 1.0 \\
& $>2.6$ & $\mathbf{1 . 5}$ & $\mathbf{1 . 3}$ & $\mathbf{2 . 8}$ & 0.6 & $\mathbf{2 . 6}$ & 0.8 & 1.2 & 0.9 \\
\hline
\end{tabular}


We observed that $\mathrm{Pb}, \mathrm{Ni}, \mathrm{Cd}$ and $\mathrm{V}$ elements which are sourced from combustion, were higher in fine dust in heating season at Göztepe and Beşiktaş. Whereas, there was an increase of the $\mathrm{Ni}, \mathrm{Pb}$ and $\mathrm{Cd}$ concentrations (between 1.4 and 2.6) in fine dust at Avc1lar. The metal concentrations at Avc1lar were higher than the other stations. We observed that there is no significant difference between heating and non-heating periods at Avcilar. It should be possible that the industrial emissions are the dominant source at Avc1lar. There is no significant difference between heating and non-heating periods at Rasathane, but at this station, $\mathrm{Mn}$ and $\mathrm{Pb}$ in fine dust were found 1.8 times and 1.7 times more, respectively (Table 2). The lowest metal concentrations were found at Kilyos background station. In the heating period, $\mathrm{Cr}, \mathrm{Cd}$ and $\mathrm{Pb}$ concentrations in fine dust was found 1.3--2.7 times higher than the concentrations in the non-heating periods at Kilyos. It should be possible that there is an air mass transport from the Blacksea. Koçak et al. [19] found that the air transport affects the element concentration of particle in Istanbul.

\section{Conclusions}

This study was conducted over two years at five different sampling locations that characterized the variations metals in eight particle size fractions in İstanbul. Generally, the highest anthropogenic metals ( $\mathrm{Pb}, \mathrm{Ni}, \mathrm{Cd}$ and $\mathrm{V}$ ) concentrations were measured in the fine fraction of particles at all stations in the heating periods. The lowest metals concentrations were measured at the Kilyos, which is in a rural area in Istanbul. Determining the overall air quality in İstanbul is quite challenging. It is a large metropolitan city and it is the center of Turkish industry, with a population of nearly 13 million. In addition, it is a city with regional differences in terms of geographical and meteorological conditions. Furthermore, the transport of pollutants into the city atmosphere from Europe and Asia accounts for a significant portion of the regional PM pollution. The physical and chemical properties of the PM samples represented the diversity of pollution sources in the city atmosphere but did not represent any specific sources. More comprehensive studies are required with more regional attributions and continuous measurements to fully evaluate the air quality of the city. In addition, it is necessary to take other constituents of particles, especially in the fine particles, into consideration to determine the overall air quality and its sources in cities.

\section{Acknowledgements}

We gratefully acknowledge the Scientific and Technical Research Council of Turkey (TUBITAK) and the Research Fund of the Istanbul University for financially supporting our study with Project No 107Y161 and T-3783, respectively. 


\section{References}

[1] Hinds, W.C., Aeresol Technology: Properties, bihavior and measurement of Airborne Particles. Second Edition. A Wiley Interscience Publication, pp. 75-100, 1999.

[2] Alvarez, F.F., Rodriguez, M.T., Espinoza, A.J.F., Daban, A.G., Physical speciation of arsenic, mercury, lead, cadmium and nickel in inhalable atmospheric particles. Analytica Chimica Acta, 524, pp. 33-40, 2004.

[3] Ny, M.T. and Lee, B.K., Size Distribution and Source Identification of Airborne Particlate Matter and Metallic Elements in a Typical Industrial City. Asian Journal of Atmospheric Environmental, 4(1), pp. 9-19, 2010.

[4] Gokhale, S.B. and Patil, R.S., Size distribution of aerosols $\left(\mathrm{PM}_{10}\right)$ and Lead $(\mathrm{Pb})$ near traffic intersections in Mumbai (India). Environmental Monitoring and Assessment, 95, pp. 311-324, 2004.

[5] Samara, C. and Voutsa, D., Size distribution of airborne particulate matter and associated heavy metals in the roadside environment. Chemosphere, 59, pp. 1197-1206, 2005.

[6] Nag, S., Gupta, A.K. and Mukhopadhyay, U.K., Size distribution of atmospheric aerosols in Kolkata, India and the Assessment of pulmonary deposition of Particle Mass. Indoor and Built Environment, 14 (5), pp. 381389, 2005.

[7] Park, S.U. and Kim, J.W., Aerosol size distributions observed at the Seoul National University campus in Korea during the Asian dust and non-Asian dust periods. Atmospheric Environment, 40, pp. 1722-1730, 2006.

[8] Goforth, M.R. and Christoforou, C.S., Particle size distribution and atmospheric metals measurements in a rural area in the South Easthern USA. Science of the Total Environment 356 (1-3), pp. 217-226, 2006.

[9] Perez, N., Pey, J., Querol, X., Alastuey, A., Lopez, J.M. and Viana, M., Partitioning of major and trace components in $\mathrm{PM}_{10}-\mathrm{PM}_{2.5}-\mathrm{PM}_{1}$ at an urban site in Southern Europe. Atmospheric Environment, 42, pp. 1677-1691, 2007.

[10] Srivastava, A. and Jain, V.K., Size distribution and source identification of total suspended particulate matter and associated heavy metals in the urban atmosphere of Delhi. Chemosphere, 68 (3), pp. 579-589, 2007.

[11] Yın, J. and Harrison, R.M., Pragmatic mass closure study for $\mathrm{PM}_{1}, \mathrm{PM}_{2.5}$ and $\mathrm{PM}_{10}$ at roadside, urban background and rural sites. Atmospheric Environment, 42, pp. 980-988, 2008.

[12] Wagner, A., Boman, J. and Gatari M.J., Elemental analysis of sizefractionated particulate matter sampled in Göteborgi Sweden. Spectrochimica Acta Part B, 63, pp. 1426-1431, 2008.

[13] Brüggemann, E., Gerwig, H., Gnauk, T., Müller, K. and Herrmann, H., Influence of seasons, air mass origin and day of the week on sizesegregated chemical composition of aerosol particles at a kerbside. Atmospheric Environment, 43(15), pp. 2456-2463, 2009. 
[14] Srivastava, A., Gupta, S. and Jain, V.K., Winter-time size distribution and source apportionment of total suspended particulate matter and associated metals in Delhi. Atmospheric Research, 92, pp. 88-99, 2009.

[15] Kopanakis, I., Lydakis, S.N., Katsivela, E., Pentari, D., Zarmpas, P., Mihalopoulos, N., and Lazaridis, M., Size Distribution and Chemical Composition of Airborne Particles at Akrotır1 Research Station, Crete, Greece. Global NEST, 12(1), pp. 54-62, 2010.

[16] Yatkın, S. and Bayram, A., Elemental composition and sources of particulate matter in the ambient air of a Metropolitan City. Atmospheric Research, 85(1), pp. 126-139, 2007.

[17] Turalığlu, F.S., Bayraktar, H. and Tuncel, G., Erzurum atmosferinde TSP, $\mathrm{PM}_{10}, \mathrm{PM}_{10-2,5}, \mathrm{PM}_{2,5}$ Kütlesel Konsantrasyonlar1. Proc. Of the National Air Quality Symposium, Konya-TURKEY, pp. 89-97, 2008. (in Turkish)

[18] Karaca, F., Alagha, O. and Ertürk, F., Statistical characterization of atmospheric PM10 and $\mathrm{PM}_{2.5}$ concentrations at a non-impacted suburban site of Istanbul, Turkey. Chemosphere, 59, pp. 1183-1190, 2005.

[19] Koçak, M., Theodosi, C., Zarmpas, P., İm, U., Bougiatioti, A., Yenigun, O. and Mihalopoulos, N., Particulate matter $\left(\mathrm{PM}_{10}\right)$ in İstanbul: Origin, source areas and potential impact on surrounding regions. Atmospheric Environment, 45(38), pp. 6891-6900, 2010.

[20] Onat, B., Şahin, Ü.A. and Bayat, C., Assessment of Particulate Matter in the Urban Atmosphere: Size Distribution, Metal Composition and Source Characterization Using Principal Component Analysis, Journal of Environmental Monitoring, 14, pp. 1400-1409, 2012.

[21] Şahin, Ü.A., Scherbakova, K. and Onat, B., Size Distribution and Seasonal Variation of Airborna Particulate Matter in Five Areas in Istanbul, Turkey. Environmental Science \& Pollution Research, 19(4), pp. 1198-1209, 2012.

[22] Querol, X., Alastuey, A., Rodriguez, S. and Plana, F., PM10 and PM2.5 source apportionment in the Barcelona Metropolitan area, Catalonia, Spain. Atmospheric Environment, 35 (36), pp. 6407-6419, 2001.

[23] Manoli, E., Voutsa, D. and Samara, C., Chemical characterization and source identification apportionment of fine and coarse air particles in Thessaloniki, Greece, Atmospheric Environment, 36, pp. 949-961, 2002.

[24] Fang, G.C., Chang, C.N., Chu, C.C., Wu Y.S., Fu P.P.C., Yang I.L. and Chen M.H., Characterization of particulate, metallic elements of TSP, $\mathrm{PM}_{2.5}$ and $\mathrm{PM}_{2.5-10}$ aerosols at a farm sampling site in Taiwan, Taichung. The Science of Total Environment, 308, pp. 157-166, 2003.

[25] Theodosi, C., Im, U., Bougiatti, A., Zarmpas, P., Yenigun O. and Mihalopoulos N., Aeresol chemical composition over Istanbul. The Science of Total Environment, 408, pp. 2482-2491, 2010.

[26] Karanasiou, A.A., Sitaras, I.E. Siskos, P.A. and Eleftheriadis, K., Size distribution and sources of trace metals and n-alkanes in the Athens urban aerosol during summer. Atmospheric Environment, 41, pp. 2368-2381, 2007.

[27] Song, F. and Gao Y., Size distribution of trace elements associated with ambient particulate matter in the affinity of a majör highway in the New 
Jersey-New York metropolitan area. Atmospheric Environment, 45, pp. 6714-6723. 2011.

[28] Majoral, C., Pape, A.L., Diot, P. and Vecellio, L., Comparison of Various Methods for Processing Cascade Impactor Data. Aeresol Science and Technology, 40, pp. 672-682, 2006.

[29] Yatin, M., Tuncel, S., Aras, N.K., Olmez, I., Aygun, S. and Tuncel, G., Atmospheric trace elements in Ankara, Turkey: 1. factors affecting chemical composition of fine particles. Atmospheric Environment, 34, pp. 1305-1318, 2000.

[30] Voutsa, D. and Samara, C., Labile and bioaccessible fractions of heavy metals in the airborne particulate matter from urban and industrial areas. Atmospheric Environment, 36, pp. 3583-3590, 2002. 